\title{
Is a Total Colectomy a Better Surgical Treatment for Spontaneous Colonic Perforation that Developed during Bevacizumab Treatment for Extra-intestinal Cancers?
}

\section{Total Kolektomi, Bağırsak Dışı Kanserlerde Bevacizumab Kullanımına Bağlı Spontan Kolonik Perforasyon Tedavisinde Daha İyi Bir Cerrahi Tedavi Olabilir Mi?}

\author{
${ }^{1}$ Acıbadem University Medical School Gastrointestinal System Research Group, İstanbul, Turkey \\ ${ }^{2}$ Acıbadem Maslak Hospital, Medical Oncology, İstanbul, Turkey \\ ${ }^{3}$ Acıbadem University Faculty of Medicine, Department of General Surgery, İstanbul, Turkey \\ ${ }^{4}$ Acıbadem Maslak Hospital, Clinic of Medical Oncology, İstanbul, Turkey \\ *Shared co-first authorship
}

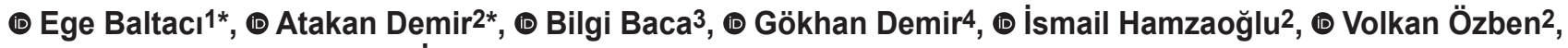
(1) Afag Aghayeva22, (1) Ahmet İsmail Bilgin2, (1) Bahadır Osman Bozkırı², (1) Erman Aytaç², (1) Tayfun Karahasanoğlu²

\section{IIIIIIII ABSTRACT}

Spontaneous colonic perforation (SCP) is a life-threatening complication of bevacizumab treatment, but data on its management is insufficient. We present five cases of SCP in patients who were receiving bevacizumab for extra-intestinal malignancies. Patients who underwent a partial colectomy at the perforation site $(n=3)$ suffered from ongoing abdominal sepsis postoperatively and died within a month. In contrast, patients who underwent total colectomy $(n=2)$ had a relatively prolonged survival and eventually died of primary disease progression. Considering the pathophysiology of bevacizumab-related SCP, a total colectomy can be a life-saving and definitive procedure when non-perforated segments of the colon appear unhealthy during intraoperative exploration.

Keywords: Bevacizumab, spontaneous colonic perforation, total colectomy

\section{|IIIIIII| ÖZ}

Spontan kolonik perforasyon, bevacizumab tedavisinin çok yüksek mortaliteyle seyreden bir komplikasyonu olmasına rağmen bu durumun yönetminine dair literatür verisi kısıtlıdır. Bu yazımızda, bağırsak dışı kanserler sebebiyle verilen Bevacizumab tedavisine sekonder gelişen beş spontan kolonik perforasyon vakası sunuyoruz. Sadece perfore segmenti içerecek şekilde parsiyel kolektomi uygulanan hastalar (n=3) ilerleyen abdominal sepsis nedeniyle postop birinci ay içerisinde kaybedilmişken, total kolektomi yapılan hastalar ( $\mathrm{n}=2$ ) görece daha uzun bir sağ kalım göstermiş olup nihai olarak primer hastalığın doğal seyri sonucu kaybedilmişlerdir. Bevacizumab tedavisine bağlı spontan kolonik perforasyonun patofizyolojisi de göz önünde bulundurulduğunda, total kolektomi, özellikle intraoperatif değerlendirmede kolonun perfore olmamış kısımlarının da sağlıksız görünmesi durumunda hayat kurtarıcı ve tek basamaklı bir tedavi olabilir.

Anahtar Kelimeler: Bevacizumab, spontan kolonik perforasyon, total kolektomi

Address for Correspondence/Yazışma Adresi: Ege Baltacı, MD,

Acrbadem University Medical School Gastrointestinal System Research Group, İstanbul, Turkey

E-mail: egebaltaci1995@gmail.com ORCID ID: orcid.org/0000-0003-0531-1919

Received/Geliş Tarihi: 08.03.2020 Accepted/Kabụl Tarihi: 21.03.2020 


\section{Introduction}

Bevacizumab is a recombinant humanised monoclonal vascular endothelial growth factor (VEGF) inhibitor. ${ }^{1}$ It inhibits neovascularisation by binding the VEGF in vascular endothelial cells of tumour tissue. ${ }^{2}$ Antiangiogenic effects of bevacizumab may cause various side effects, including haemorrhage, bowel perforation, wound healing complications, thromboembolism, congestive heart failure, hypertension and infusion-related hypersensitivity reactions. Spontaneous colonic perforation (SCP) is a lifethreatening complication of bevacizumab when it is used for advanced colorectal cancer. ${ }^{3}$ In addition, patients under treatment for extra-intestinal cancers, including ovarian, lung, kidney, cervical and brain cancers, are at risk of SCP. ${ }^{4,5}$ However, data on clinical characteristics and management strategies for SCP in patients under bevacizumab treatment for extra-intestinal cancers are limited. In this report, the clinical characteristics and outcomes of management strategies of five patients who developed SCP while being under bevacizumab treatment for extra-intestinal cancers in our institution are reviewed.

\section{Case Report}

From 2016 to 2018, five patients underwent surgery for SCP while undergoing bevacizumab treatment for extraintestinal cancers (Table 1). All patients had abdominal pain as their initial presentation with typical physical findings of acute abdomen, and abdominal computed tomography (CT) scans that revealed free fluid and intraperitoneal air densities. The perforation sites were the sigmoid colon $(n=2)$, the caecum $(n=2)$ and the transverse colon $(n=1)$. In two patients with a caecal perforation, total colectomy with an end ileostomy was performed because of the inflamed and structurally weak appearance of the rest of the colon. These patients were discharged from the hospital with no further operative complications. In the other two patients with sigmoid colon perforation, a left colectomy with an end colostomy was performed. These patients suffered from ongoing abdominal sepsis and died within a month postoperatively. In the last patient with a transverse colon perforation, a transverse colectomy with an endto-end anastomosis was performed. However, this patient developed another free perforation in the right colon. Thus, a right colectomy with an end ileostomy was performed during the reoperation. This patient died of systemic sepsis two weeks after the reoperation.

Overall, patients who underwent a total colectomy were discharged from the hospital and died of underlying disease progression after a comparably more extended period compared with those who underwent segmental colonic

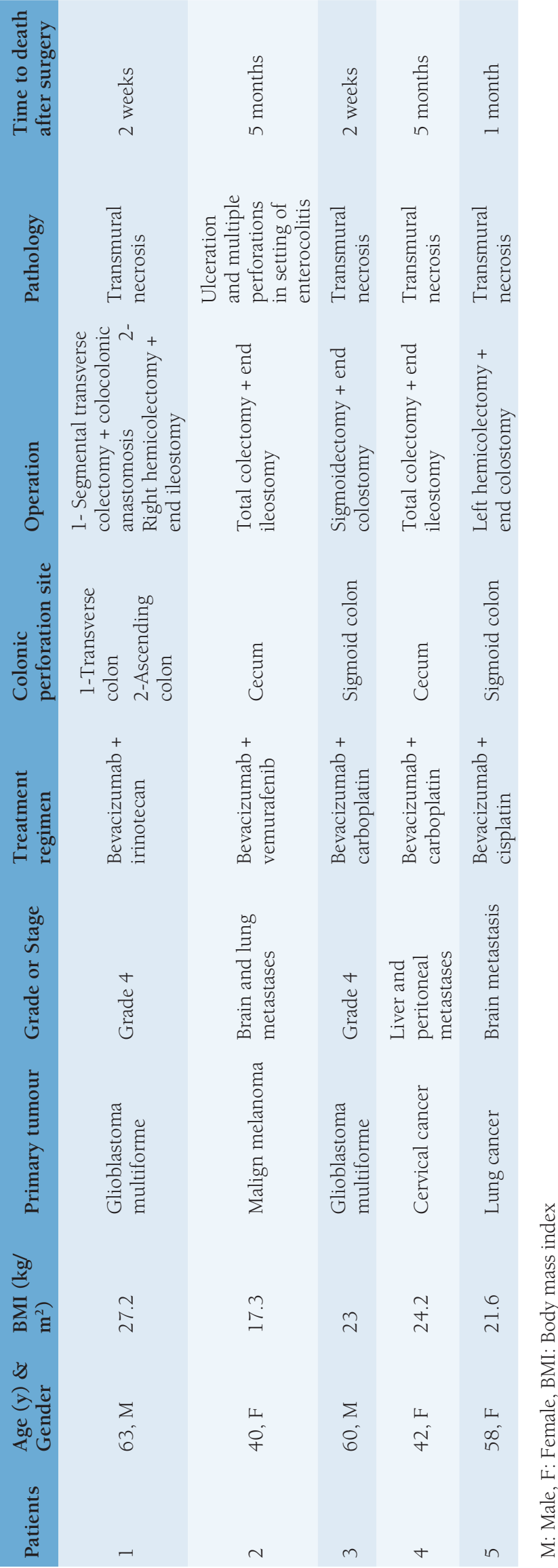


resections who died of either ongoing abdominal/systemic sepsis or second colonic perforation.

\section{Discussion}

Two histopathologic findings related to bowel perforations due to bevacizumab use were found in our cases. First, the necrosis of the metastatic lesion on the colonic wall. Second, wide, adjoining ulcerations or transmural necrosis of non-metastatic sites of the colon with haemorrhagic infarcts and thrombosed small- and medium-sized vessels that led to perforations. The first mechanism directly explains the pathophysiology of bevacizumab-related SCP due to necrosis of a primary or metastatic tumour on the colonic wall. ${ }^{6,7}$ Removing the perforated segment of the colon should solve the problem when the remnant colon is considered healthy. However, VEGF inhibition causes regenerative capacity loss of the whole colon by diminishing the microcirculation and decreasing nitrous oxide and prostacyclin production. ${ }^{6,7}$ Therefore, the whole colon may become prone to complications due to the systemic effects of bevacizumab treatment, since the adverse effects of this drug impair the micro-structure of the whole colon in addition to the perforation site.

Bevacizumab is a known inducer of colonic inflammation. ${ }^{8}$ Colitis and accompanying stasis significantly increase bacterial translocation. ${ }^{9}$ Total colectomy is the preferred surgical procedure for complicated ulcerative colitis. Therefore, removal by this procedure would also prevent further life-threatening complications of colonic perforation in patients under bevacizumab treatment. Following the segmental removal of the perforation site of the colon, increased bacterial translocation can occur from the remnant colon via the pathologic pathways related to VEGF inhibition. Of the five cases presented, patients who underwent a partial colectomy of the perforation site suffered from ongoing sepsis postoperatively. They died within a month after the index surgery, presumably due to this mechanism.

While non-operative treatment has been reported to be a safe option for patients with bevacizumab-related gastrointestinal perforations in general $^{4,10}$, colonic perforations require special attention because of their faecal load. In cases with acute abdomen and ongoing sepsis, a surgical approach is usually mandatory. Removal of the whole diseased colon may potentially prevent further septic complications and early mortality, as is the case in toxic colitis.

Considering these patients' poor life expectancy and fragile condition, total colectomy with an end ileostomy can be a life-saving, single-stage, definitive procedure for bevacizumab-induced colonic perforations. Further studies with larger numbers of patients will provide more reliable data for the management of this subset of patients.

\section{Ethics}

Informed Consent: Informed consents were obtained from all the patients.

Peer-review: Externally peer reviewed.

\section{Authorship Contributions}

Surgical and Medical Practices: E.B., B.B., G.D., İ.H., V.Ö., A.A., A.I.B., B.O.B., E.A., T.K., Concept: E.B., B.B., V.Ö., A.A., A.İ.B., Design: A.D., B.B., Data Collection or Processing: E.B., A.D., B.B., Analysis or Interpretation: E.B., A.D., B.B., G.D., Literature Search: A.D., B.B., G.D., Writing: E.B., A.D., B.B.

Conflict of Interest: No conflict of interest was declared by the authors.

Financial Disclosure: The authors declared that this study received no financial support.

\section{References}

1. Avastin (bevacizumab) Information https://www.fda.gov/Drugs/ DrugSafety/ucm 193900.htm

2. Roodhart JM, Langenberg MH, Witteveen E, Voest EE. The Molecular Basis of Class Side Effects Due to Treatment with Inhibitors of the VEGF/VEGFR Pathway. Curr Clin Pharmacol 2008;3:132-143.

3. Fujii Y, Hirahara N, Kaji S, Taniura T, Hyakudomi R, Yamamoto T, Tajima Y. Bevacizumab-induced intestinal perforation in a patient with inoperable breast cancer: a case report and review of the literature. J Med Case Rep 2018;12:84

4. Badgwell BD, Camp ER, Feig B, Wolff RA, Eng C, Ellis LM, Cormier JN. Management of bevacizumab-associated bowel perforation: a case series and review of the literature. Ann Oncol 2008;19:577-582.

5. Hapani S, Chu D, Wu S. Risk of gastrointestinal perforation in patients with cancer treated with bevacizumab: a meta-analysis. Lancet Oncol 2009;10:559-568

6. Sliesoraitis S, Tawfik B. Bevacizumab-Induced Bowel Perforation. J Am Osteopath Assoc 2011;111:437-441.

7. Choi YI, Lee SH, Ahn BK, Baek SU, Park SJ, Kim YS, Shin SH. Intestinal perforation in colorectal cancers treated with bevacizumab (Avastin). Cancer Res Treat 2008;40:33-35.

8. Freeman HJ. Colitis associated with biological agents. World J Gastroenterol 2012;18:1871-1874.

9. Asfaha S, MacNaughton WK, Appleyard CB, Chadee K, Wallace JL. Persistent epithelial dysfunction and bacterial translocation after resolution of intestinal inflammation. Am J Physiol Gastrointest Liver Physiol 2001;281:G635-G644.

10. Borofsky SE, Levine MS, Rubesin SE, Tanyi JL, Chu CS, Lev-Toaff AS. Bevacizumab-induced perforation of the gastrointestinal tract: clinical and radiographic findings in 11 patients. Abdom Imaging 2013;38:265-272. 